\title{
Determining long- term changes in a skate assemblage with aggregated landings and limited species data
}

\author{
Marandel Florianne ${ }^{1}$, Lorance Pascal ${ }^{1}$, Trenkel Verena ${ }^{1, *}$ \\ ${ }^{1}$ Ifremer, Nantes, France \\ *Corresponding author : Verena Trenkel, email address : verena.trenkel@ifremer.fr
}

\begin{abstract}
:
Sustainable fisheries management requires assessment of exploited populations and communities. Traditional fisheries stock assessment methods need species-specific input data, which for skates have only recently become available in Europe. To overcome this limitation, a Bayesian multispecies biomass production model was developed. In addition to aggregated landings, input data are short time series with species-specific information (landings and biomass indices). Applying the approach to four main skate species and a group of two skate species, all managed together in the Bay of Biscay (Northeast Atlantic), long-term changes in the skate assemblage composition were identified. Since the 1990s, Leucoraja naevus became increasingly dominant, while the contributions of the other three species (Raja brachyura, Raja clavata and Raja montagui) declined. The abundance of the grouped Leucoraja fullonica and L. circularis has also strongly decreased, suggesting long-term overexploitation. All species except this species group are expected to increase over the next decade under current harvest rates. Currently, the species considered here are managed under a single fishing quota making it unlikely that the group of the two most depleted species will recover soon. The multispecies modelling approach bears promise for other harvested assemblages for which only grouped harvest information is available for certain periods.
\end{abstract}

Keywords: community changes, fishing impacts, multispecies management, multispecies model, Rajiformes, species composition, vulnerable skates 


\section{Acknowledgements}

We thank Eloi Lezian for preliminary work on the model and the GDR EcoStat for constructive comments on preliminary models. The study received funding from the French “Agence Nationale de la Recherche" (project GenoPopTaille, contract ANR-14-CE02-000601), the Fondation Total (project GenoPopTaille-Capsules) and the European Union's Horizon 2020 research and innovation programme under Grant Agreement No 773713 (PANDORA). We thank two anonymous reviewers for useful comments. 


\section{Introduction}

A major objective of ecosystem-based fisheries management is to maintain species and size diversity within exploited ecosystems (Livingston, Aydin, Boldt, Ianelli, \& JuradoMolina, 2005). Rajiformes, hereafter referred to as "skates", is a species-rich order containing some 382 species out of ca. 1209 elasmobranchs species and, whilst morphologically conservative, this order displays a range of life-history traits (Dulvy et al., 2017; WoRMS Editorial Board, 2017). Elasmobranchs display relatively low fecundity and high sensitivity to overfishing (Stevens, Bonfil, Dulvy, \& Walker, 2000).

A lack of fishing limits, habitat loss, and climate change resulted in a decline of several elasmobranch populations around the world during the 20th century (Dulvy et al., 2014; Dulvy et al., 2017; Quéro \& Cendrero, 1996). In the North Sea the European Union (EU) introduced fishing quotas for skates only in 1999, which were generalized to all EU Atlantic waters, including the Bay of Biscay, in 2009 (EC, 1999, 2009). This lack of management prior to 1999 led to changes in species composition: in the southern North Sea, the elasmobranch assemblage shifted from larger species to smaller and more productive species between 1902 and 2013 (Sguotti, Lynam, Garcia-Carreras, Ellis, \& Engelhard, 2016). Similarly, a change in elasmobranch community composition over the last half century was found in the Adriatic Sea (Ferretti, Osio, Jenkins, Rosenberg, \& Lotze, 2013). The main driver of this change was overexploitation (Barausse et al., 2014). In both areas the large bodied angel shark (Squatina squatina, Linnaeus, 1758) has been extirpated (Ferretti et al., 2013; Sguotti et al., 2016). This species was once also rather common in the Bay of Biscay (Quéro \& Cendrero, 1996). Globally, predation release seems to have been an important driver for increases in certain skate species, with reduced fishing mortality playing a smaller role (see review in Ward-Paige, Keith, Worm, and Lotze (2012)). 
In the last decade, the majority of reported landings of skates from the Bay of Biscay comprised four ray species: blonde ray Raja brachyura Lafont, 1871; thornback ray Raja clavata Linnaeus, 1758; spotted ray Raja montagui Fowler, 1910 and cuckoo ray Leucoraja naevus (Müller \& Henle, 1841) (ICES, 2016). The main fisheries exploiting skates in the Bay of Biscay are trawl fisheries, which have represented $70 \%$ and $90 \%$ of landings of $R$. clavata, L. naevus L. fullonica and L. circularis respectively in recent years (ICES, 2017, 2018a). $R$. clavata is also caught by coastal small-scale longlining and netting. The more coastal $R$. brachyura and $R$. montagui are primarily landed by vessels using passive gears ((ICES, 2018d, 2018f)). The large contribution of trawling to catches of skates prevailed during and even before the study period (Du Buit, 1974; Letaconnoux, 1948) making skates primarily a bycatch of fisheries for the main bentho-demersal species such as hake, monkfishes, sole and megrim. Like elsewhere in European waters, fishing effort increased in the second half of the 20th century, generating harvest rates in excess of maximum sustainable yield (MSY) levels from the 1960s for numerous teleost stocks, and started decreasing at the turn of the $21 \mathrm{st}$ century (Fernandes \& Cook, 2013; Mesnil, 2008). Two other skates species, sandy ray Leucoraja circularis (Couch, 1838) and shagreen ray Leucoraja fullonica (Linnaeus, 1758), are also present in recent landings with indications for higher past abundances at least in the northern part of the Bay of Biscay (Du Buit, 1974). These six species ( $R$. brachyura, $R$ clavata, R. montagui, L. circularis, L. fullonica, and L. naevus), were therefore considered in this study. Other Rajiformes occurring on the Bay of Biscay shelf and upper slope include undulate ray Raja undulata Lacepède, 1802; small-eyed ray Raja microocellata Montagu, 1818; white skate Rostroraja alba (Lacepède, 1803), Dipturus batis (Linnaeus, 1758) complex (blue skate composed of two species) and longnose skate Dipturus oxyrinchus (Linnaeus, 1758). These other species were not considered because they have either been subject to landing bans since 2009 , occur at low abundance, or data are even more uncertain 
than for the six species studied here. The studied species are small- to medium-sized skates occurring from shallow waters to the shelf break and have uncertain life history trait (Supporting information S1, Table S1.1).

Except for rare cases with very long survey time series (e.g. North Sea, Sguotti et al. (2016)), estimation of long-term time trends of skates has to rely on fishery-dependent data which unfortunately is hampered by low abundances commonly resulting in insufficient observations (Kuhnert, Griffiths, \& Brewer, 2011). Whilst there have been improvements to the species-specific reporting of skate landings since 2009 (EC, 2009), landings prior to this were generally reported as "miscellaneous rays and skates" if not "miscellaneous sharks and rays". In order to investigate long term changes in the Bay of Biscay skate assemblage in such a data limited situation, a multispecies biomass model that uses historic landings aggregated across species and more recent species-specific landing and survey time series was developed. To account for uncertainty in landings and survey time series as well as in life history information, a Bayesian approach was used to fit the multispecies model. The effect of different data combinations and variants of prior information on species and composition time trends was explored. The main aim was to obtain robust estimates of time trends in a data limited situation which is rather common for species which are not the main target of fisheries and hence do not benefit from appropriate sampling and recording programs.

\section{Methods}

\section{Data}

All data are available in supporting information (Supporting information S3). 


\section{Commercial landings and fishery}

Aggregated commercial landings for the studied species for the period 1950 to 2008 were derived from official landing statistics (see Supporting information S1). Species-specific landings were available for 2009-2016 and used to account for removals from the fishery and as data source to inform on recent species composition.

\section{Biomass indices}

Biomass indices were calculated for each species using data from the scientific bottom trawl survey (EVHOE - ÉValuation des ressources Halieutiques de l'Ouest de l'Europe) carried out in the Bay of Biscay from 1987 to 2016 (with missing years when the considered species were not observed or no survey was carried out) (Figure 1b-f; description of index calculation in Supporting Information S1). For L. naevus and the three Raja species, the time series was expanded using data from 1973 and 1976 collected with the same trawl and sampling plan (but limited to depths shallower than $200 \mathrm{~m}$ ). For L. fullonica and L. circularis, as the number of individuals caught in the survey was small leading to very imprecise indices, data were combined into a single "other Leucoraja spp." index and biomass indices were calculated using hauls from the Bay of Biscay and the adjacent Celtic Sea to cover the spatial distribution and increase the number of individuals caught. Consequently, biomass indices of L. naevus and Raja species were available for the years 1973, 1976 and 1987-2016 (including missing years) and for other Leucoraja spp. for 1997-2016 (including missing years).

\section{Modelling}

\section{Model}

The state-space biomass production model is a multispecies extension of the discrete-time model developed for thornback ray by Marandel, Lorance, and Trenkel (2016), see Table 1. 
To overcome the lack of species-specific landings before 2009, the probability of aggregated landings having been from species $e$ in year $t$ was assumed to correspond to estimated biomass proportions in the previous year $t-1$. This assumption implies that there was no species-specific targeting before 2009 and fisheries selectivity for each species was constant over time and among species.

The observation model links population biomass to the biomass indices. Assuming landings are proportional to species biomasses, observed species-specific landings for 20092016 were also used to inform biomass composition for these years.

\section{Model fitting and runs}

The model was fitted using a Bayesian approach. Information on prior distributions and other technical issues can be found in the supporting information S1. In brief, informative priors were created for intrinsic growth rates $r_{e}$ (Supporting information S1, Table S1.2) using life history parameters (McAllister, Pikitch, \& Babcock, 2001) while uninformative priors

were used for carrying capacities $K_{e}$ (table 2). The prior for the process variance $\sigma^{2}$ was chosen to be moderately informative while the observation variances ( $\tau^{2}$ for biomass indices and $\rho^{2}$ for species composition in landings) were assumed known (Table 2). For survey catchabilities $q_{e}$ the priors had most mass $<0.5$, for this Beta $(1,3)$ was used for all species.

As no information was available concerning the initial relative biomass of each species in 1950, two sets of priors were tested for $Y O_{e}$ (see Table 1) corresponding to two depletion hypotheses (Table 2). For the BASE run, all species were assumed underexploited in 1950 (prior mode $\mathrm{YO}_{e}=0.8$ ) (see Table 2). For the EXPL run, all species were assumed fully exploited in 1950 (prior mode $Y O_{e}=0.5$ ). In addition, to evaluate the impact of corrections made of the aggregated landings (described in Supporting information S1) a third run called SHORT was carried out using a shorter time series during which little landings corrections 
were made and biomass indices were available. The SHORT run used landings from 1973 and assumed all species were fully exploited in 1973. The BASE and the EXPL runs were compared using the DIC (Deviance Information Criterion) and residuals were inspected to assess model fit.

\section{Analyses}

Changes in estimated species composition were studied in terms of the relative contribution of each species to total assemblage biomass. To evaluate the impact of fishing, harvest rates were calculated for each species by dividing estimated (known after 2009) landings by estimated biomass in each year (Table 1). Harvest rates where standardized by dividing them by the harvest rate leading to maximum sustainable yield harvest rates (Table 1).

To explore recovery potential under current (status quo) harvest rates, populations of all species, except L. naevus (no recovery needed), were simulated forward 10 years assuming constant harvest rates (mean for 2014-2016). To evaluate the effect of harvest reduction on species recovery constant harvest rates set at 0.5 status quo and no harvest were also simulated. The robustness of these projections was evaluated by comparing them to projections carried out starting from the fitted SHORT run and a shortened BASE run for which the 2016 data was removed.

The BASE run assuming underexploitation in 1950 was thought to be the most realistic run as French fishing power increased until the early 1990s (Mesnil, 2008). Further, hake, megrim and sole stocks (the only demersal stocks occurring in the Bay of Biscay with long time series assessed by ICES) were still above SSBMSY in the early 1980s (ICES, 2018b, 2018c, 2018e). Therefore results are presented primarily for the BASE run. 


\section{Results}

\section{Model runs}

For all model runs posterior distributions for $\mathrm{YO}_{e}$ were identical to prior distributions indicating that the data did not permit estimating the initial depletion levels (Supporting information S2, Fig S.2.1). Model fits for the two depletion runs were identical (BASE DIC=1434; EXPL DIC=1434). Detailed results for the SHORT and the EXPL runs are provided in supporting information S2. Residuals of smoothed biomass indices and speciesspecific landings indicated satisfactory model fit (BASE run Figure S2.2 and S2.3).

\section{Assemblage changes}

Without exploitation, populations are expected to vary around their carrying capacity $(K)$. In this situation, based on posterior mean estimates of $K$, the smallest species L. naevus was estimated to be the most abundant species (38\% of assemblage biomass), followed by the other Leucoraja spp. (27\%) and R. clavata (17\%) (Figure 2a and Figure S2.4). R. brachyura and $R$. montagui were estimated to have the smallest biomass contributions ( $8 \%$ and $9 \%$ respectively).

The mean estimated species composition in 1950 was driven by the prior distributions for $Y O_{e}$ and hence similar to the unexploited situation (Figure 2b). Between 1950 and 1991 the estimated proportion of L. naevus remained constant with a small decrease in the 1970s, whilst $R$. clavata increased to $41 \%$, thus becoming the dominant species (in biomass). After this L. naevus increasingly dominated the species composition, reaching $63 \%$ of the assemblage biomass in 2017. The estimated proportions of $R$. brachyura and $R$. montagui continuously decreased until 2010 and increased thereafter. The estimated proportion of other Leucoraja spp. decreased continuously over the study period. The species composition results 
were insensitive to assumptions regarding initial depletion and time series length (see Figure S2.4 for results for EXPL and SHORT runs).

In the observed landings, the proportion of L. naevus decreased slightly from $78 \%$ in 2009 to $66 \%$ in 2016 , while those of all other species except $R$. clavata increased (Figure 2c). The observed landings composition in 2009 was similar though not identical to the estimated assemblage composition in the same year.

\section{Population changes}

The estimated biomass of all species, except L. naevus, decreased generally between 1950 and around 2009 and increased over the most recent decade (Figure 3; Figure S2.5). L. naevus first decreased between 1950 and 1991 ( $-2.1 \%$ per year $)$ and increased thereafter $(+1.8 \%$ per year); the overall decrease between 1950 and 2017 was 20\%. Its biomass in 2017 was estimated to be close to $64 \%$ of its carrying capacity (95 percentile interval: $46-83 \%$ ). The decrease of $R$. clavata strongly accelerated after 1995 with the 2017 biomass being at around $40 \%$ of carrying capacity (95 PI: 25-55\%). R. montagui decreased until 1995 (-1.94\% per year), initially strongly, and increased after 2008 (+12\% per year); its 2017 biomass was at $40 \%$ of carrying capacity (95 PI: 18-66\%). R. brachyura followed a similar pattern with a strong decrease until 2009 (-1.65\% per year) and an increase thereafter; the biomass in 2017 was estimated at $25 \%$ of carrying capacity (95 PI: 8-44\%). Other Leucoraja spp. reached the lowest biomass in 2000 and increased to 8\% (95 PI: 10-17\%) in 2017.

Between 1950 and 1980 estimated annual landings for R. clavata, L. naevus and the other Leucoraja spp. were generally above 1000 t, decreasing thereafter for all species (Figure 3, Figure S2.6). Until the early 1990s relative harvest rate estimates indicated overexploitation for all species, in particular other Leucoraja spp. (values $>1$ in Figure 3, Figure S2.7). After 
2011 harvest rates were estimated to be at or below MSY values for all species except for the other Leucoraja spp.

The highest carrying capacity $K$ was found for the small offshore $L$. naevus, followed by other Leucoraja spp. and $R$. clavata. $R$. brachyura and $R$. montagui had similar estimated $K$ (Figure S2.8). However absolute values are uncertain as there was a negative correlation between estimates of $K$ and survey catchability $q$ as well as between $K$ and intrinsic growth rates $r$ (Figure S2.12). The informative priors for $r$ were somewhat updated for all species: posterior estimates were larger than priors for $L$. naevus and $R$. clavata while for the other species posterior estimates were smaller (Figure S2.9). The fact that the data contained information on $r$ implies that the estimated maximum sustainable yield values were not completely determined by a priori knowledge. For the process error $\sigma^{2}$ prior and posterior distributions were identical (Figure S2.10).

\section{Short-term projections}

Projecting the two depleted species and the grouped species $\left(Y_{e, 2017}<0.4\right)$ forwards indicated that under current harvest rates $R$. clavata and $R$. montagui are expected to increase above $50 \%$ of carrying capacity (corresponding to the MSY biomass level) within the next

five years (Figure 4). Even without fishing the other Leucoraja spp. are not expected to increase much by 2028 (from 8\% of carrying capacity in 2018 to 12\% in 2028). Under status quo harvesting $R$. brachyura is predicted to increase to $41 \%$ (PI 16-66) of carrying capacity within ten years, halving the harvest rate would make it reach the same depletion level within around seven years.

The projections results for the SHORT run and the shortened BASE run were generally similar, thus confirming the robustness of projections, except that $R$. clavata is predicted to take around three years longer for the shortened BASE run to reach MSY biomass (Figure 
S2.11). For $R$. montagui the SHORT run estimated population biomass to be already at MSY level in 2017.

\section{Discussion}

Understanding changes in exploited elasmobranch communities is challenging, as it requires disentangling the effects of exploitation and changes in predation, competition and environmental conditions, in a data limited situation (Ferretti et al. 2013). To overcome the data limitation for skates in the Bay of Biscay, in particular the lack of species-specific landings for most of the time period, a Bayesian approach simultaneously modelling all species was developed. Applying this approach indicated that the total biomass of the six considered skate species has declined strongly in the Bay of Biscay since the 1950s. In 2017, only L. naevus was estimated to be above $50 \%$ of its carrying capacity; three species $(R$. brachyura, $R$. montagui and $R$. clavata) were estimated to be between 20 and $40 \%$ of their carrying capacity while the grouped other Leucoraja spp. were estimated to be $<10 \%$. Whilst the actual values are uncertain, the relative order of species should be more robust. Comparable composition changes have been reported in the Irish Sea, where L. naevus increased and $R$. clavata and $R$. montagui decreased between the early $1960 \mathrm{~s}$ and the $1990 \mathrm{~s}$ (Dulvy, Metcalfe, Glanville, Pawson, \& Reynolds, 2000).

The assemblage composition in 1950 might have been close to what would be expected without fishing. In contrast, since the 1990s the small offshore L. naevus increasingly dominated the assemblage, while the contribution decreased for the populations of mediumsized species, the offshore other Leucoraja spp. and the coastal $R$. brachyura. For all species, harvest rates throughout most of the 67 years were larger than those leading to maximum sustainable fisheries yield, indicating overfishing by coastal fisheries as well as fisheries on the continental slope as a major factor for their strong decline. While L. naevus is also found 
on the continental slope, its higher intrinsic growth rate compared to the other Leucoraja spp. might explain why it sustained exploitation better. For $R$. clavata, the wide bathymetric distribution, from coastal to the upper continental slope (Supplementary information S1, Table S1.1), might have created refuges from fishing, as there is little targeted skate fishing, except in coastal areas. Analysing data from the Celtic Sea, Shephard, Gerritsen, Kaiser, and Reid (2012) concluded that the spatial heterogeneity of fishing created refuges for elasmobranchs in this area. To evaluate the potential refuge effect in the Bay of Biscay, an analysis of the spatial overlap of fishing and species distributions would be needed. Unfortunately, the spatial coverage of the bottom trawl survey was insufficient in coastal waters for the data to be useable for such an analysis. Further, the insufficient coverage of coastal waters might have hampered derivation of robust biomass indices for $R$. brachyura and $R$. montagui which are primarily found in coastal waters. Hence the results for these two species should be interpreted with caution. Further, as the spatial distribution of $L$. circularis and L. fullonica extends further offshore than the survey area, any changes in spatial distribution will have biased biomass indices. However, we do not know of any evidence for such changes.

Prior to the 2000s, skate catches were mostly unmanaged in European waters. The total allowable catch (TAC) for Rajiformes, introduced in 2009 in the study area, may not have been limiting from the start but has been reduced from $6400 \mathrm{t}$ in 2009 to $3400 \mathrm{t}$ in 2016 with this TAC covering both the Bay of Biscay and the western Iberian shelf. As a reaction to the limited catch opportunities, some fishers' producer organisations and governments have added various rules, such as a cap on landings per trip and minimum landing sizes. For example in France, skates smaller than $45 \mathrm{~cm}$ total length cannot be landed (JORF, 2017) and are therefore discarded at sea. As skates have been considered to be amongst the fish species that might survive discarding (Depestele, Desender, Benoit, Polet, \& Vincx, 2014; Knotek, 
Rudders, Mandelman, Benoit, \& Sulikowski, 2018; Morfin, Mehault, Benoit, \& Kopp, 2017), discarding rather than landing all catches may have helped reduce fishing mortality. If this effect is sufficiently large, it should lead to an increase in biomass, though with some delay (Collie, Rochet, \& Bell, 2013). Thus, the biomass increases observed in recent years for most species might at least partially be due to reduced fishing mortality caused by increased discarding in addition to reduced fishing fleet capacity (Mesnil, 2008). Unfortunately there is a lack of discard information to test this hypothesis.

Predation release is another factor which has been used to explain community changes (Myers, Baum, Shepherd, Powers, \& Peterson, 2007; Shepherd \& Myers, 2005; Ward-Paige et al., 2012). Several large elasmobranch species have declined in the Bay of Biscay, including S. squatina (Quéro \& Cendrero, 1996), D. batis complex and R. alba. Stomach content information collected in the English Channel in the 1930s indicated that large $(>120$ cm) D. batis feed on both R. montagui and L. naevus (Pinnegar, 2014). Hence predation release might be a potential explanation for the more recent increase in $L$. naevus and $R$. montagui, though perhaps to a different degree for the two species. Large and small skates may also have overlapping feeding niches (Smale \& Cowley, 1992), which could have led to competition release.

Assuming constant intrinsic population growth rates and carrying capacities over several decades is clearly a simplification. Changes in environmental conditions, habitat, competition and predation might have modified both parameters. Also, changes in the species composition of the benthos in favour of scavengers such as some gastropods, may modify predation rates on substrate-attached skate eggs (Lucifora \& Garcia, 2004). Further, different factors are likely to have affected the six species in different ways. However, the developed model included a process error which accommodates unknown changes in $r$ and $K$ when estimating biomasses. 
The multi-species Bayesian model provided an effective way for integrating aggregated landings with species-specific biomass indices and life history information (informative prior distributions for intrinsic growth rates) to study long-term changes for species which could not be investigated otherwise due to insufficient data, or only making even stronger assumptions.

Given the problem of aggregated landings is widespread (Reuter et al., 2010), we believe the approach has potential for being applied in other areas. To the best of our knowledge, only few published studies have modelled the abundance of data poor stocks abundance based on aggregated catches (but see Bell, Fogarty, and Collie (2014)). However, the suitability of the approach critically depends on the assumption of landings having been roughly proportional to biomasses (and vice versa for years with species-specific landings). This assumption might be relaxed if proxies of fisheries targeting are available. In this case, a model estimating the relative fisheries catchability of each species (or species group) could be developed.

Survey indices were smoothed after initial runs showed problems with model fitting. To improve raw indices and avoid the need for smoothing, survey spatial coverage and the number of hauls would need to be adapted to the spatial distribution and low density of skate species. For example, $R$. brachyura and $R$. montagui are primarily inshore species mostly abundant by depth <40m (Quéro \& Vayne, 1997) while the EVHOE survey is mainly further offshore (Poulard \& Trenkel, 2007). In contrast, the depth range (Supporting information S1, Table S1.1) L. circularis and L. fullonica, which were modelled as other Leucoraja spp., is well covered by the survey (around $90 \%$ of hauls are between $80 \mathrm{~m}$ and $600 \mathrm{~m}$ ). Thus for these species the sampling plan might be well adapted in terms of spatial coverage, though not in terms of number of hauls. 
In conclusion, the group of other Leucoraja spp. and R. brachyura were found to have decreased strongly during the study period and to have too high current harvest rates making them the primary species of concern for management. In contrast, abundant species, in particular L. naevus, seem to be able to sustain the current levels of harvesting.

\section{Supporting information}

Supporting information S1, S2 and S3 are available at the online version of the article.

\section{References}

Barausse, A., Correale, V., Curkovic, A., Finotto, L., Riginella, E., . . Mazzoldi, C. (2014). The role of fisheries and the environment in driving the decline of elasmobranchs in the northern Adriatic Sea. ICES Journal of Marine Science, 71(7), 1593-1603. doi:10.1093/icesjms/fst222

Bell, R. J., Fogarty, M. J., \& Collie, J. S. (2014). Stability in marine fish communities. Marine Ecology Progress Series, 504, 221-239. doi:10.3354/meps10730

Collie, J., Rochet, M.-J., \& Bell, R. (2013). Rebuilding fish communities: the ghost of fisheries past and the virtue of patience. Ecological Applications, 23(2), 374-391.

Depestele, J., Desender, M., Benoit, H. P., Polet, H., \& Vincx, M. (2014). Short-term survival of discarded target fish and non-target invertebrate species in the "eurocutter" beam trawl fishery of the southern North Sea. Fisheries Research, 154, 82-92. doi:10.1016/j.fishres.2014.01.018

Du Buit, M. H. (1974). Contribution à l'étude des populations de raies du Nord-Est Atlantique des Faeroe au Portugal. (PhD), Paris. 
Dulvy, N. K., Fowler, S. L., Musick, J. A., Cavanagh, R. D., Kyne, P. M., . . White, W. T. (2014). Extinction risk and conservation of the world's sharks and rays. Elife, 3, eLife.00590. doi:10.7554/eLife.00590

Dulvy, N. K., Metcalfe, J. D., Glanville, J., Pawson, M. G., \& Reynolds, J. D. (2000). Fishery stability, local extinctions, and shifts in community structure in skates. Conservation Biology, 14(1), 283-293. doi:10.1046/j.1523-1739.2000.98540.x

Dulvy, N. K., Simpfendorfer, C. A., Davidson, L. N. K., Fordham, S. V., Brautigam, A., . . .Welch, D. J. (2017). Challenges and Priorities in Shark and Ray Conservation. Current Biology, 27(11), R565-R572. doi:10.1016/j.cub.2017.04.038

EC. (1999). COUNCIL REGULATION (EC) No 48/1999 of 18 December 1998 fixing, for certain fish stocks and groups of fish stocks, the total allowable catches for 1999 and certain conditions under which they may be fished. Official Journal of the European Communities, L13, 1-53.

EC. (2009). No 43/2009 of 16 January 2009 fixing for 2009 the fishing opportunities and associated conditions for certain fish stocks and groups of fish stocks, applicable in Community waters and, for Community vessels, in waters where catch limitations are required, (2009).

Fernandes, P. G., \& Cook, R. M. (2013). Reversal of Fish Stock Decline in the Northeast Atlantic. Current Biology, 23(15), 1432-1437. doi:10.1016/j.cub.2013.06.016

Ferretti, F., Osio, G. C., Jenkins, C. J., Rosenberg, A. A., \& Lotze, H. K. (2013). Long-term change in a meso-predator community in response to prolonged and heterogeneous human impact. Scientific Reports, 3. doi:10.1038/srep01057

ICES. (2016). Report of the Working Group on Elasmobranchs Fishes (WGEF). Retrieved from http://www.ices.dk/publications/library 
ICES. (2017). Thornback ray (Raja clavata) in Subarea 8 (Bay of Biscay). ICES Advice on fishing opportunities, catch, and effort,Bay of Biscay and the Iberian Coast Ecoregion. ICES Advice 2016, Book 7. Retrieved from http://www.ices.dk/publications/library

ICES. (2018a). Cuckoo ray (Leucoraja naevus) in subareas 6 and 7 and divisions 8.a-b and 8.d (West of Scotland, southern Celtic Seas, and western English Channel, Bay of Biscay) Retrieved from https://doi.org/10.17895/ices.pub.4580

ICES. (2018b). Hake (Merluccius merluccius) in subareas 4, 6, and 7, and in divisions 3.a, 8.a-b, and 8.d, Northern stock (Greater North Sea, Celtic Seas, and the northern Bay of Biscay). Advice on fishing opportunities, catch, and effort, Greater Northern Sea, Celtic Seas, and Bay of Biscay and Iberian Coast ecoregions, Published 29 June 2018, 10pp. Retrieved from https://doi.org/10.17895/ices.pub.4463b

ICES. (2018c). Megrim (Lepidorhombus whiffiagonis) in divisions 7.b-k, 8.a-b, and 8.d (west and southwest of Ireland, Bay of Biscay)Advice on fishing opportunities, catch, and effort, Bay of Biscay and the Iberian Coast, Celtic Seas, Greater North Sea, and Oceanic Northeast Atlantic ecoregions. Published 29 June 2018, 8pp. Retrieved from https://doi.org/10.17895/ices.pub.4460

ICES. (2018d). Other skates and rays in Subarea 8 and Division 9.a (Bay of Biscay and Atlantic Iberian waters), Published 5 October 2018, 7pp. Retrieved from https://doi.org/10.17895/ices.pub.4556

ICES. (2018e). Sole (Solea solea) in divisions 8.a-b (northern and central Bay of Biscay). ICES Advice on fishing pportunities, catch, and effort, Bay of Biscay and the Iberian Coast Ecoregion, Published 19 July 2018, 8pp. Retrieved from https://doi.org/10.17895/ices.pub.4449 
ICES. (2018f). Spotted ray (Raja montagui) in Subarea 8 (Bay of Biscay), Published 5 October 2018, 4pp. Retrieved from https://doi.org/10.17895/ices.pub.4560

JORF. (2017). Arrêté du 21 mars 2017 modifiant l'arrêté du 28 janvier 2013 déterminant la taille ou le poids minimal de capture et de débarquement des poissons et autres organismes marins pour la pêche professionnelle. doi:DEVM1707953A

Knotek, R. J., Rudders, D. B., Mandelman, J. W., Benoit, H. P., \& Sulikowski, J. A. (2018). The survival of rajids discarded in the New England scallop dredge fisheries. Fisheries Research, 198, 50-62. doi:10.1016/j.fishres.2017.10.015

Kuhnert, P. M., Griffiths, S., \& Brewer, D. (2011). Assessing population changes in bycatch species using fishery-dependent catch rate data. Fisheries Research, 108(1), 15-21. doi:10.1016/j.fishres.2010.11.014

Letaconnoux, R. (1948). Effets de la guerre sur la constitution des stocks de poissons. Rapports et Procès-Verbaux des Réunions du Conseil Permanent International pour l'Exploration de la Mer, 122, 55-62.

Livingston, P. A., Aydin, K., Boldt, J., Ianelli, J., \& Jurado-Molina, J. (2005). A framework for ecosystem impacts assessment using an indicator approach. ICES Journal of Marine Science, 62, 592-597. doi:10.1016/j.icesjms.2004.12.016

Lucifora, L. O., \& Garcia, V. B. (2004). Gastropod predation on egg cases of skates (Chondrichthyes, Rajidae) in the southwestern Atlantic: quantification and life history implications. Marine Biology, 145(5), 917-922. doi:10.1007/s00227-004-1377-8

Marandel, F., Lorance, P., \& Trenkel, V. M. (2016). A Bayesian state-space model to estimate population biomass with catch and limited survey data: application to the thornback ray (Raja clavata) in the Bay of Biscay. Aquatic Living Resources, 29(2), 209. doi:10.1051/alr/2016020 
McAllister, M. K., Pikitch, E. K., \& Babcock, E. A. (2001). Using demographic methods to construct Bayesian priors for the intrinsic rate of increase in the Schaefer model and implications for stock rebuilding. Canadian Journal of Fisheries and Aquatic Sciences, 58(9), 1871-1890. doi:10.1139/cjfas-58-9-1871

Mesnil, B. (2008). Public-aided crises in the French fishing sector. Ocean \& Coastal Management, 51, 689-700.

Morfin, M., Mehault, S., Benoit, H. P., \& Kopp, D. (2017). Narrowing down the number of species requiring detailed study as candidates for the EU Common Fisheries Policy discard ban. Marine Policy, 77, 23-29. doi:10.1016/j.marpol.2016.12.003

Myers, R. A., Baum, J. K., Shepherd, T. D., Powers, S. P., \& Peterson, C. H. (2007). Cascading effects of the loss of apex predatory sharks from a coastal ocean. Science, 315(5820), 1846-1850. doi:10.1126/science.1138657

Pinnegar, J. K. (2014). DAPSTOM - An Integrated Database \& Portal for Fish Stomach Records.

Poulard, J.-C., \& Trenkel, V. M. (2007). Do survey design and wind conditions influence survey indices? Canadian Journal of Fisheries and Aquatic Sciences, 64, 1551-1562.

Quéro, J.-C., \& Cendrero, P. (1996). Incidence de la pêche sur la biodiversité ichtyologique marine: le bassin d'Archachon et le plateau continental Sud Gascogne. Cybium, 20, 323-356.

Quéro, J.-C., \& Vayne, J.-J. (Eds.). (1997). Les poissons de mer des pêches françaises: identification, inventaire et répartition de 209 espèces. Lausanne: Delachaux et Niestlé.

Reuter, R. F., Conners, M. E., Dicosimo, J., Gaichas, S., Ormseth, O., \& Tenbrink, T. T. (2010). Managing non-target, data-poor species using catch limits: lessons from the Alaskan groundfish fishery. Fisheries Management and Ecology, 17, 323-335. 
Sguotti, C., Lynam, C. P., Garcia-Carreras, B., Ellis, J. R., \& Engelhard, G. H. (2016). Distribution of skates and sharks in the North Sea: 112 years of change. Global Change Biology, 22(8), 2729-2743. doi:10.1111/gcb.13316

Shephard, S., Gerritsen, H., Kaiser, M. J., \& Reid, D. G. (2012). Spatial heterogeneity in fishing creates de facto refugia for endangered Celtic Sea elasmobranchs. PLoS ONE, 7(11). doi:10.1371/journal.pone.0049307

Shepherd, T. D., \& Myers, R. A. (2005). Direct and indirect fishery effects on small coastal elasmobranchs in the northern Gulf of Mexico. Ecology Letters, 8(10), 1095-1104. doi:10.1111/j.1461-0248.2005.00807.x

Smale, M. J., \& Cowley, P. D. (1992). The feeding ecology of skates (Batoidea, Rajidae) off the Cape South coast, South-Africa. South African Journal of Marine Science, 12, 823-834.

Stevens, J. D., Bonfil, R., Dulvy, N. K., \& Walker, P. A. (2000). The effects of fishing on sharks, rays, and chimaeras (chondrichthyans), and the implications for marine ecosystems. ICES Journal of Marine Science, 57(3), 476-494. doi:10.1006/jmsc.2000.0724

Ward-Paige, C. A., Keith, D. M., Worm, B., \& Lotze, H. K. (2012). Recovery potential and conservation options for elasmobranchs. Journal of Fish Biology, 80(5), 1844-1869. doi:10.1111/j.1095-8649.2012.03246.x

WoRMS Editorial Board. (2017). World Register of Marine Species. Available from http://www.marinespecies.org at VLIZ. Accessed 2018-02-18. 


\section{Tables}

Table 1. Model equations, parameter description and variable distributions.

\begin{tabular}{|c|c|c|}
\hline Model equations & Description & Distributions \\
\hline General & $\begin{array}{l}e \text { species } \\
t \text { year }\end{array}$ & \\
\hline $\begin{array}{l}\text { Process model } \\
\text { Population dynamics } 1950 \text { to } 2008 \text { : } \\
Y_{e, t+1} \sim N\left(\left(r_{e}+1\right) Y_{e, t}-r_{e} Y_{e, t}^{2}-\frac{C_{e, t}}{K_{e}}, \sigma^{2}\right) \\
Y_{e, t}=\frac{B_{e, t}}{K_{e}} \\
Y_{e, 1}=Y O_{e} \\
\text { Predicting landings } 1950 \text { to } 2008: \\
C_{t} \sim M u l t i\left(\boldsymbol{p}_{t}, C_{t o t, t}\right) \\
p_{e, t}=\frac{B_{e, t-1}}{\sum_{e} B_{e, t-1}} \\
\text { Population dynamics } 2009 \text { to } 2016: \\
Y_{e, t+1} \sim N\left(\left(r_{e}+1\right) Y_{e, t}-r_{e} Y_{e, t}^{2}-\frac{l_{e, t}}{K_{e}}, \sigma^{2}\right)\end{array}$ & $\begin{array}{l}Y_{e, t} \text { relative biomass } \\
Y O_{e} \text { relative biomass in } \\
1950 \\
\sigma^{2} \text { variance for relative } \\
\text { biomass } \\
B_{e, t} \text { absolute biomass } \\
r_{e} \text { intrinsic growth rate } \\
K_{e} \text { carrying capacity } \\
C_{\mathrm{e}, t} \text { predicted landings } \\
p_{e, t \quad \text { probability of }} \\
\text { landings being from } \\
\text { species } e \\
C_{\text {tot, }} \text { observed aggregated } \\
\text { landings } \\
l_{e, t} \text { observed landings by } \\
\text { species }\end{array}$ & $\begin{array}{l}Y: \text { truncated normal } \\
\left(Y_{\mathrm{e}, \mathrm{t} \geq 0)}\right. \\
C: \text { multinomial }\end{array}$ \\
\hline $\begin{array}{l}\text { Observation model } \\
\text { Biomass index } 1973 \text { (1997) to } 2016 \text { : } \\
I_{e, t} \sim N\left(q_{e} B_{e, t}, \tau_{e}^{2}\right) \\
\text { Landings proportions } 2009 \text { to } 2016 \\
\qquad l_{e, t} \sim N\left(\frac{B_{e, t-1}}{\sum_{e} B_{e, t-1}} C_{t o t, t}, \rho^{2}\right)\end{array}$ & $\begin{array}{l}I_{e, t} \text { biomass index } \\
q_{e} \text { survey catchability } \\
\tau_{e}^{2} \text { variance of biomass } \\
\text { index } \\
\rho^{2} \text { variance of landings } \\
\text { proportions }\end{array}$ & $\begin{array}{l}\text { I: truncated normal }(I \\
\geq 0) \\
\text { l: truncated normal } \\
(1 \geq 0)\end{array}$ \\
\hline $\begin{array}{l}\text { Harvest rates } \\
h_{e, t}=C_{e, t} / B_{e, t} \\
h_{M S Y}=r_{e} / 2\end{array}$ & $\begin{array}{l}h_{e, t} \text { harvest rate } \\
h_{M S Y} \text { maximum } \\
\text { sustainable yield harvest } \\
\text { rate }\end{array}$ & \\
\hline
\end{tabular}


Table 2: Prior distributions and data used for model runs.

\begin{tabular}{|c|c|c|c|c|c|c|}
\hline Run & Species & Landings & $\begin{array}{l}r \sim \text { Beta } \\
\text { mode, sd }\end{array}$ & $\begin{array}{l}\text { Y0 Beta } \\
\text { mode, sd }\end{array}$ & $\begin{array}{c}\text { K Uniform } \\
\text { min,max }\end{array}$ & $\begin{array}{c}1 / \sigma^{2} \sim \text { Gamma } \\
\text { mode, } \mathrm{sd}\end{array}$ \\
\hline \multirow{5}{*}{ BASE } & L. naevus & \multirow{5}{*}{$1950-2016$} & $0.132,0.05$ & $0.8,0.10$ & 2000,800000 & 400,1 \\
\hline & R. clavata & & $0.105,0.05$ & $0.8,0.10$ & 2000,250000 & 400,1 \\
\hline & R. montagui & & $0.114,0.05$ & $0.8,0.10$ & 2000,250000 & 400,1 \\
\hline & R. brachyura & & $0.091,0.05$ & $0.8,0.10$ & 2000,250000 & 400,1 \\
\hline & $\begin{array}{c}\text { Other Leucoraja } \\
\text { spp. }\end{array}$ & & $0.098,0.05$ & $0.8,0.10$ & 2000,250000 & 400,1 \\
\hline \multirow{4}{*}{ EXPL } & L. naevus & \multirow{4}{*}{$1950-2016$} & \multirow{4}{*}{ as above } & $0.5,0.10$ & \multirow{4}{*}{ as above } & \multirow{4}{*}{ as above } \\
\hline & R. clavata & & & $0.5,0.10$ & & \\
\hline & $\begin{array}{l}R \text {. montagui } \\
R \text {. brachyura }\end{array}$ & & & $\begin{array}{l}0.5,0.10 \\
0.5,0.10\end{array}$ & & \\
\hline & $\begin{array}{c}\text { Other Leucoraja } \\
\text { spp. }\end{array}$ & & & $0.5,0.10$ & & \\
\hline \multirow{4}{*}{ SHORT } & L. naevus & \multirow{4}{*}{ 1973-2016 } & \multirow{4}{*}{ as above } & $0.5,0.10$ & \multirow{4}{*}{ as above } & \multirow{4}{*}{ as above } \\
\hline & R. clavata & & & $0.5,0.10$ & & \\
\hline & $\begin{array}{l}\text { R. montagui } \\
\text { R. brachyura }\end{array}$ & & & $\begin{array}{l}0.5,0.10 \\
0.5,0.10\end{array}$ & & \\
\hline & $\begin{array}{c}\text { Other Leucoraja } \\
\text { spp. }\end{array}$ & & & $0.5,0.10$ & & \\
\hline
\end{tabular}




\section{Figure legends}

FIGURE 1. a) Aggregated landings in tonnes for the Rajidae Species (Rajidae, Rajiformes, Raja spp, L. naevus, L. circularis, L. fullonica, R. clavata, R. brachyura and R. montagui) from (ICES 2017, 2016, 2011) and specific landings for $R$. brachyura, $R$. clavata, $R$. montagui, L. naevus and the other Leucoraja spp. from (ICES 2016). Survey biomass indices and smoothed indices for (b) R. montagui, (c) R. brachyura, (d) other Leucoraja spp., (e) L. naevus and (f) R. clavata.

FIGURE 2. a) Species composition at carrying capacity for the five studied species; b) Mean estimated species composition between 1950 and 2017; c) Observed species composition in landings between 2009 and 2016.

FIGURE 3. Estimated relative biomass between 1950 and 2017 (top row), landings (tonnes) between 1950 and 2016 (middle row) and relative harvest rates between 1950 and 2016 (bottom row) for the studied ray species (mean values with 95\% percentile bands). Dashed horizontal lines for relative harvest rates correspond to maximum sustainable yield ( $\left.h_{\mathrm{MSY}}\right)$.

FIGURE 4. Projected relative biomass for three species and the species group under three harvest regimes (coded with color and linetype) (mean values with 95\% percentile bands). 


\section{Figures}
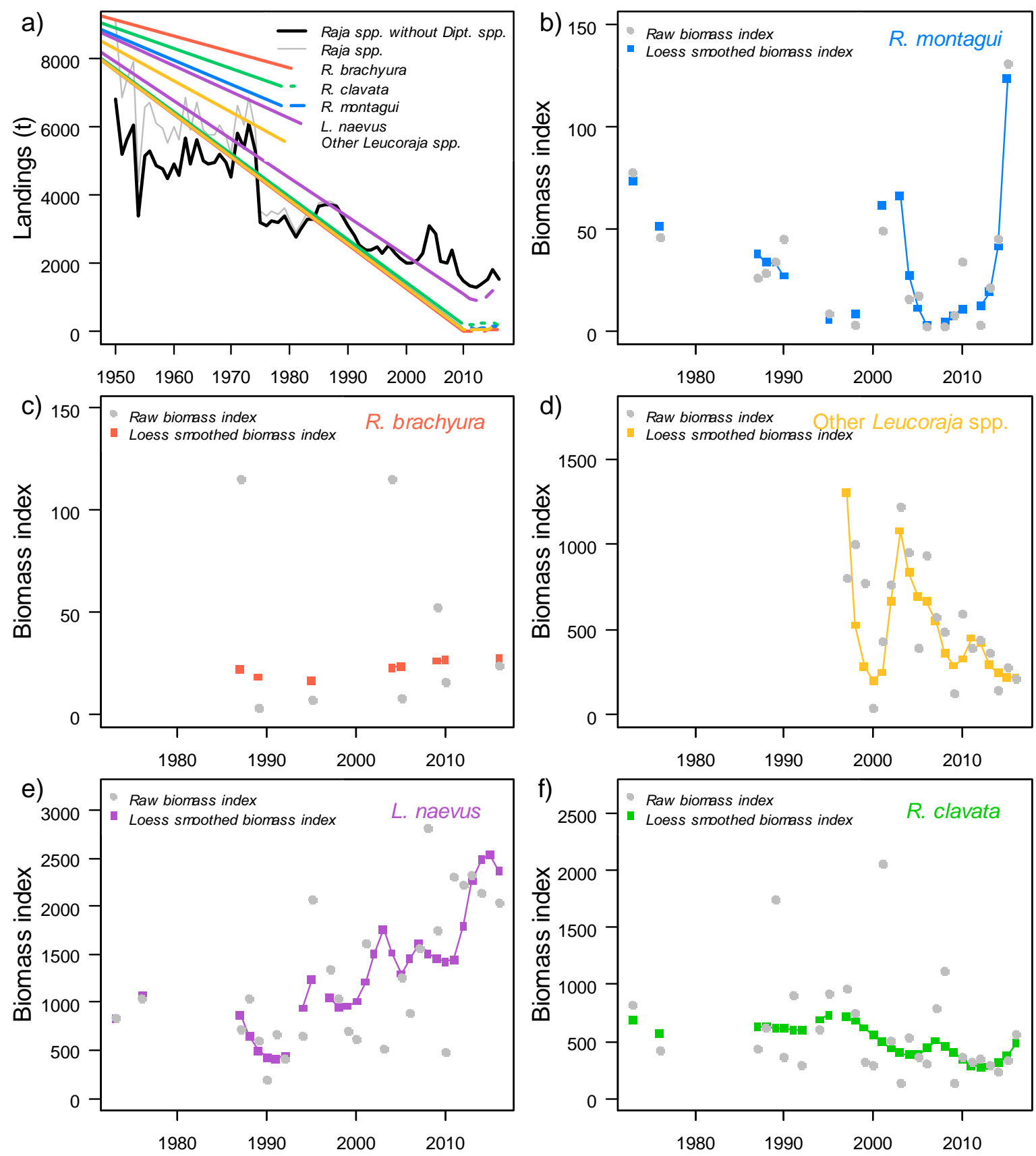

FIGURE 1. a) Aggregated landings of Rajiformes in tonnes from (ICES 2017, 2016, 2011) and species-specific landings for Raja brachyura, R. clavata, R. montagui, Leucoraja naevus and L. fullonica and L. circularis grouped as other Leucoraja spp. from (ICES 2016). Survey biomass indices and smoothed indices for (b) R. montagui, (c) R. brachyura, (d) other Leucoraja spp., (e) L. naevus and (f) R. clavata. 

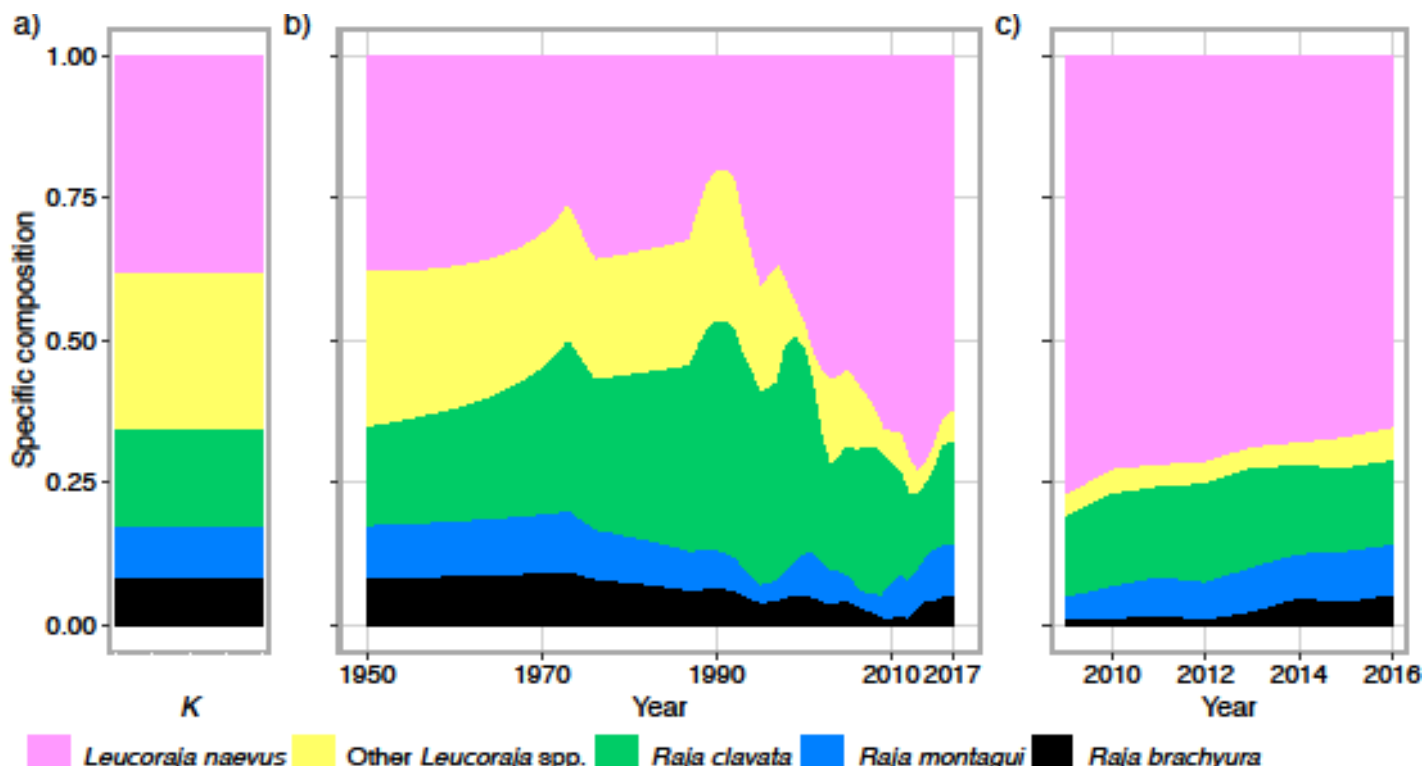

FIGURE 2. a) Species composition at carrying capacity for the five studied species; b) Mean estimated species composition between 1950 and 2017; c) Observed species composition in landings between 2009 and 2016. 


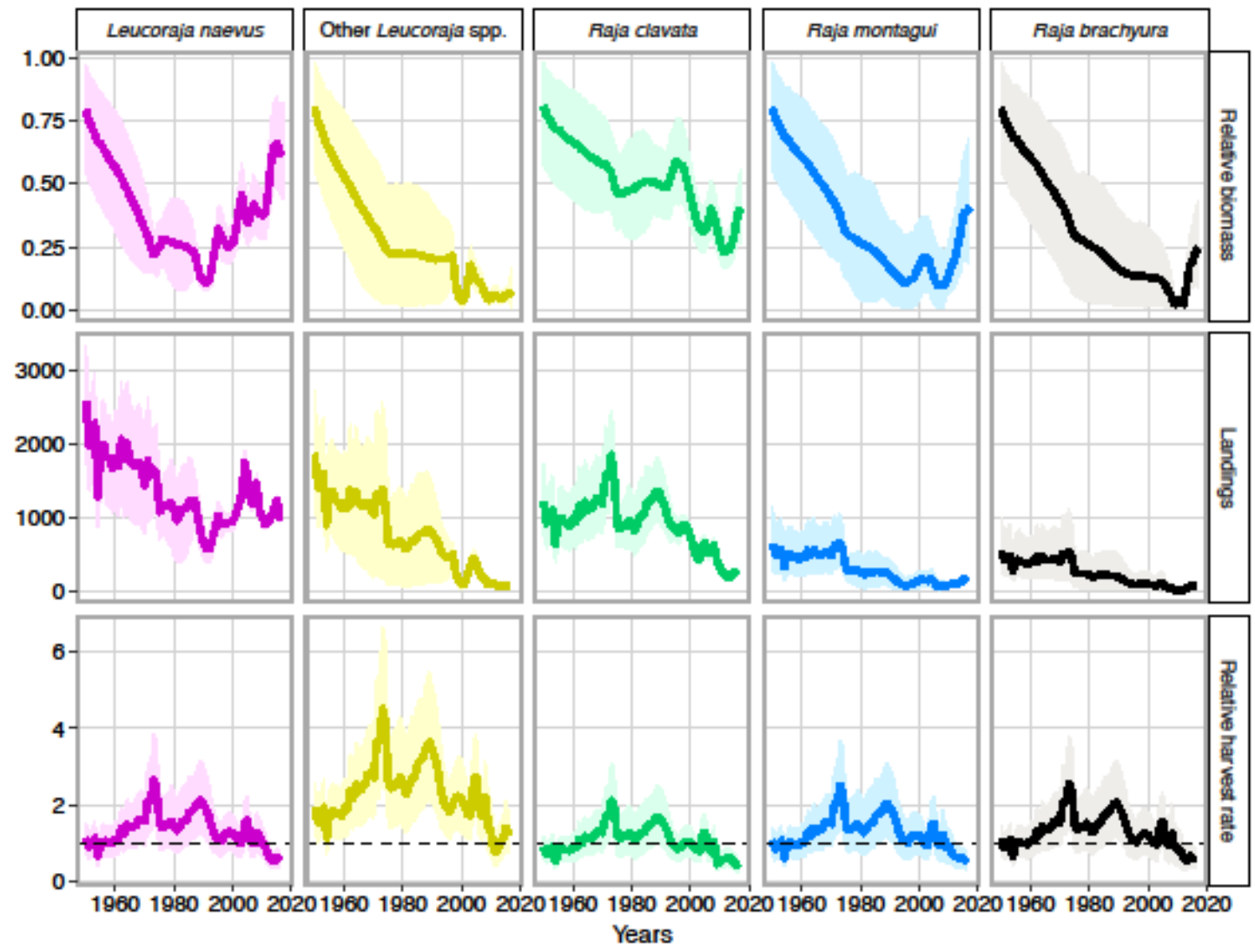

FIGURE 3. Estimated relative biomass between 1950 and 2017 (top row), landings (tonnes) between 1950 and 2016 (middle row) and relative harvest rates between 1950 and 2016 (bottom row) for the studied ray species (mean values with $95 \%$ percentile bands). Dashed horizontal lines for relative harvest rates correspond to maximum sustainable yield. 


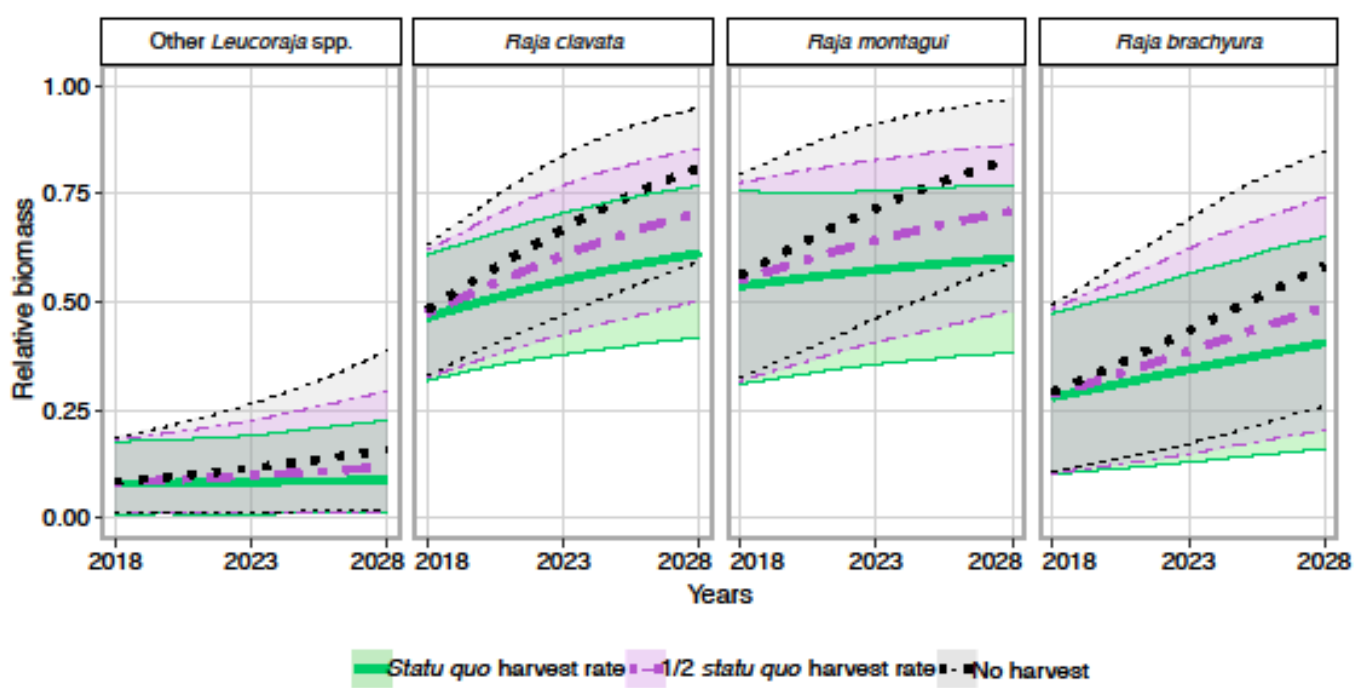

FIGURE 4. Projected relative biomass for three species and the species group under three harvest regimes (color and linetype) (mean values with 95\% percentile bands). 